\title{
Children's Perspectives on Health: What Makes Children Feel Good According to Themselves?
}

\author{
Ebba Kostmann (Corresponding author) \\ Department of Nursing, Health and Culture \\ University West \\ SE-461 86 Trollhättan, Sweden
}

Tel: 46-703-697-936Ｅ-mail: ebba.kostmann@vgregion.se

\author{
Lena Nilsson \\ Department of Nursing, Health and Culture \\ University West \\ SE-461 86 Trollhättan, Sweden \\ Tel: 46-520-223-877Ｅ-mail: lena.a.nilsson@hv.se
}

Received: August 31, 2011 Accepted: September 4, 2011 Published: March 1, 2012

doi:10.5296/ije.v4i1.914

URL: http://dx.doi.org/10.5296/ije.v4i1.914

\begin{abstract}
The object of this study is to examine children's perspectives on health and what elements make them feel good. Health promoting contributions rarely emanate from children's perspectives but most often from a child perspective, what adults consider children need in order to feel well. There are relatively few studies made from children's viewpoints on health - children should be made more involved in the shaping of health interventions. The study was carried out at two nine-year compulsory schools in Western Sweden, 78 pupils aged 9 through 11years participated. To collect the material interviews was the principal source, and the result is mainly supported by an analysis of the contents from 52 interviews. What the children declared to be the most important element for health were relations. This circumstance was stated in 88 percent of the interviews, and it was in substance the relations to family and friends that were brought up. A condition to lift children's perspectives is that they are taken seriously, that their part-taking leads to influence and a real utilization of their opinions. A conclusion from this study is that activities that handle health for children and young people should consider children's perspectives: partly through focusing the work on promoting children's social and familial relations, and partly to let the children participate more in the final shape of contents and working methods.
\end{abstract}

Keywords: Children's perspectives, Participation, Health, Relations 
The Health Adventure The Oasis Vara, is a part of the regional work with public health in the Swedish region Västra Götaland, whose vision is to promote the health of children and young people. The personnel, i.e. the health educationists, meet children, young people and adults in both programmes and studies within the fields of health, parenthood, friendship, love, and relations. The Health Adventure is continuously developing and improving the work. According to Nilsson (2008) it should be investigated within this development work whether the field of activities is founded on children's thoughts about health, or on the health educationists' thoughts on what children need in order to promote their health.

\section{Child perspective or children's perspectives}

It is quite common that educationists that work with children take a child perspective instead of children's perspectives. That means that they proceed from their own view, what adults think children need in order to feel well, instead of starting with children's perspectives. Grown-ups are in a higher position of power, and they take for granted that they know more than children, and that children do not know what is best for them. It is the task for adults to make sure that children do the right thing, and that they learn certain things - the educationist has a normative mission. In this instance it is not possible or necessary that the educationist follows the will of the child. Children's perspectives, unlike child perspective, is a matter of children expressing their views. The educationist is in this case endeavouring to meet the child on its own conditions through reasoning, listening and talking. The adult person tries to compromise and reach agreements through taking part of the children's thoughts (E. Johansson, 2003). To utilize children's perspectives implies that their participation leads to influence and real utilization (Pramling Samuelsson \& Sheridan, 2003). According to the UN Convention on the Rights of the Child (commonly abbreviated as the CRC, CROC, or UNCRC) and Article 12, children have the right to have their opinion heard and to participate in decisions that affect them (Unicef, 2008).

Traditionally, childhood and children's lives have only been investigated from an adult perspective and from the adults' understanding of them. Children have been excluded from research processes; they have not been included in democratic processes or in making decisions (Christensen \& James, 2008). In research within the field of sociology children used to be likened to incomplete adults who should be filled with knowledge and capability through the socializing process. They were viewed as a homogenous group who experienced childhood the same way independent of society and surrounding factors. In the 1980's these notions started to be challenged and researchers assumed children's perspectives to a larger extent (Matthews, 2007; Prout, 2005). Childhood started to be seen as a place that children themselves take possession of and not only a process where they are to be socialized into society (James \& Prout, 1997). Children are viewed as social participants who interact with their environment (Christensen \& James, 2008; Matthews, 2007).

\section{Children's perspectives on health}

In order to investigate children's perspectives the target group children has been ever-increasingly involved in research contexts during the last decades. Through various methods they have communicated their perspectives within several different fields, for 
example school (Alerby, 2003) and home environment (Hume, J. Salmon, \& Ball, 2005). Through research they have been able to share their ideas on health but then often with focus on a specific theme, for example mental health (A. Johansson, Brunnberg, \& Eriksson, 2007), healthy eating (Hesketh, Waters, Green, L. Salmon, \& Williams, 2005) and physical activity (Birtwistle \& Brodie, 1991). There are also studies where children's perspectives on health are explored in a more general way, and according to those there are a few different factors that make children feel well. Healthy food, sports, training, hygiene and sleep (Pridmore \& Bendelow, 1995) were most important to those children participating in an English study. In Kenya, children aged 10 to 15 years considered well-being to consist of being happy, healthy, physically active, and being able to have a good personal hygiene (Onyango-Ouma, Aargaard-Hansen, \& Jensen, 2004). In the study by Piko and Bak (2006) it turned out that the concept of health to children in Hungary, aged 8 to 11 years, included physical, psychical and social elements. The children felt good from being happy, healthy and having good friends at school. In a study done in Sweden (Kostenius, 2008) it was concluded that children chiefly thrive from good relations, to be included and to feel confidence in friends, parents, teachers but also pets. To the children it is important to care about each other and to be included. Trust in others makes them feel safe and helps them to confide in people. The relations are characterized by love, support, helpfulness, openness, and listening.

\section{Children's participation}

Children have been dealt rights, and their participation in society has increased, but there is still a lot of work to do to create participation, on children's conditions. According to the Swedish Ombudsman for Children most municipalities, rural districts, county councils and regions in Sweden have made the decision to work according to the UNCRC, but the challenge lies in putting decisions into action. Many children experience that they are not treated in a way that is in compliance with the intentions of the UNCRC (Barnombudsmannen, 2009). Participation and influence are important to children's health, and there are several studies that show the connection between these elements (Wennerholm Juslin \& Bremberg, 2004). Although most Swedish children and young people have good health, reports from the last few years seem to show a down-going tendency (Socialstyrelsen, 2009). This concerns primarily the mental health and observed over time somatic as well as mental strains seem to increase (Danielsson, 2006). Early work may diminish the costs for society for mental ill-health (Skolverket, Socialstyrelsen, \& Statens folkhälsoinstitut, 2004), but then the assets should be spent where they may give most effect. In order to improve the health of children and young people they will have to express themselves what makes them feel well.

According to Kostenius, (2008) more research is needed on health and well-being from children's perspectives, which is still a relatively unexplored theme (Piko \& Bak, 2006). The current health promoting work needs to be more adjusted to children's needs, and that children get to participate more in the shaping of the interventions (Kalnins, McQueen, Backett, Curtice, \& Currie, 1992; Ryan, 1998). For a public activity like The Health Adventure, whose vision is to promote the health of children and young people, it is of great importance to let children participate to a higher degree. The health educationists, who create 
interventions for the children, must ask themselves if their field of activities is founded on children's thoughts about health, or on their own thoughts on what children need in order to promote their health? The purpose of this study is therefore to investigate children's perspectives on health, what makes them feel good according to themselves. The conception of health in this context is to be understood from a promoting perspective, and from now on it will be used synonymous with well-being and comfort.

\section{Method}

Two nine-year compulsory schools from the region of Västra Götaland took part in the study during October through December 2008. A multicultural school in a metropolitan area (school A) and a non-multicultural school in a rural part of Sweden (school B). To increase the reliability of the study it was important to choose schools where the pupils had different backgrounds and environmental conditions. Since The Health Adventure work in this Swedish region, earlier contacts and geographic location also founded the decision that those were to be the schools. The total number of pupils was 78. The children that participated in the study were in the forms three to five, at the ages of nine to eleven years. This form was elected because the personnel from The Health Adventure often meet children at this age performing health activities within their organization.

The study has a qualitative approach since there are several advantages to use this when the target group is children; they often give comprehensive descriptions through their own words and pictures (Greig, Taylor, \& Mackay, 2007). The main method to collect material was through interviews and conversations with the children. The character of the interviews was investigative and had the intention to make the child share his or her thoughts on the special theme. This method helps the adult to understand the thinking of the child and through that knowledge, it is possible to create a better learning environment and also to evaluate the educational work (Doverborg \& Pramling Samuelsson, 2007). An individual task was also carried out and in this we used writing-and-drawing techniques (Piko \& Bak, 2006; Pridmore \& Bendelow, 1995). When research is done with children the interviewer is not familiar with, it is important to get to know them and for that time is needed with the children (Doverborg \& Pramling Samuelsson, 2007; E. Johansson, 2003). For this reason the interviewers visited the classes involved on several occasions. During this time the individual task was performed where the children wrote and/or drew the things that gave them comfort. Interviews were done individually, in pairs or in groups of three, and they were taped by a dictating machine. Our aim was to explore the children's perspectives on health and what makes children feel good according to themselves. The conversations therefore followed an interview outline with comprehensive issues about what makes them themselves feel well, what makes children as a group feel well, and also what the body/soul needs in order to thrive. Finally there is a question about how they view the concept of health. All the interviews were semi-structured since it was possible to change the order of the questions and the attendant questions (Greig et al., 2007). The headmasters at the schools gave their permission for the study to be performed in the classes concerned. Participation in the study was voluntary for the children, but in order to do research every child has to have basic information about the study and thereafter give his or her consent (Alderson, 2004; Hill, 2005). 


\subsection{Analysis proceedings}

After the individual task the children's production was collected, and it was recorded in a table how often different things had been drawn or written about. Thereafter these things were arranged according to themes. The material from the interviews was transcribed, and then an analysis of content was performed on the texts (Miles \& Huberman, 1994). The material was analyzed based on the children as a group, and because of that there was no difference made between boys and girls. The result from the schools A and B are shown below jointly along the themes and categories that were crystallized concerning what makes children feel well.

\section{Result}

The individual task where children were asked to draw and/or write what made them feel well, was performed by 77 out of 78 children. From the materials that were put together the following themes were distinguished:

- Family

- Friends

- Animals

- Play/do sports

- TV/computer/listen to music

- School

- School holidays

- Travel

- Visit fun-fair/public baths

The themes above are similar to the result of the interviews, whose contents were presented in four categories: relations, physical activities, basic needs and other categories. The children's thoughts on what makes the body feel well, and their view on the concept of health are also presented. The occurrence of a category is shown in percent, which equals the number of conversations in which the category was mentioned. Since the children could give more than one answer during the interviews, the total sum is larger than 52, i.e. more than 100 percent. Altogether 52 conversations were accomplished with 67 pupils: 33 at school A and 19 at school B. The average interview lasted about 25 minutes, but the time varied between 10 minutes and 50 minutes.

\subsection{Relations}

In the majority of the interviews, 88 percent, the children express that relations make themfeel well, chiefly relations to family and friends/pals. In about half of the conversations they say that friends/pals are important for their well-being, and in almost as many interviews relations to the own family is important. In this category there was no big difference between what children think is important to themselves, and what is important to children as a group. 
One child responded the following on a question asking what is important to children:

"That you have parents that are present. Love. Gadgets are just gadgets".

The children said that their families made them feel well because they were nice to them. Parents give them cooked food and presents, they drive them to sport activities and so on. Brothers and sisters also give comfort because you can play and have fun with them, even though they can be tiresome at times. Also relations to relatives and animals were important, but not at all to the same extent. Friends give well-being because they are good to play with, they are kind, they can think of fun things to do, and they give a sense of security. One child described the importance of relations like this:

"Children feel well from taking care of each other, that they, for example, play with somebody even though they are not buddies”.

\subsection{Physical activities}

In a little more than half of the conversations, 53 percent, the children said that physical activity made them feel good, but however, not at all as many said that other children felt good from it. Physical activity was about training, sporting or playing. One child explained why it was important in this way:

\section{“...if you don't exercise you will be stiff and tired when you are a grown-up”.}

The kind of training that was most popular was team sports of different kinds. Football was the most common sport, but also ice-hockey, badminton, table tennis, tennis and swimming were instances of sports that the children said that they practised. What it was in the sporting itself that the children liked was not always concluded. One child liked football because then you could go to cups. Another said that the best part about ice-hockey was to see the friends on the team. A third child said that the best thing with badminton was to win.

\subsection{Basic needs}

The children mentioned that to have the basic needs like food, drink, sleep and a good health made them feel well in almost half of the conversations, 48 percent. It was mainly eating and drinking that was mentioned, but then they were chiefly talking about children as a group, not themselves. Some of them related to children in other countries:

\section{"Children in Africa don't have a lot of food, food is important..."}

\subsection{Other categories}

Other categories that were distinguished among the children were multimedia, entertainment and learning. In 44 percent of the conversations multimedia like TV, computers and music were brought up as something that made the children themselves feel good. In 42 percent of the interviews entertainment was mentioned as something that made children feel good. Especially pleasures in the shape of parties, visits to amusement parks, the play-and-mischief-ground in Gothenburg and the water parks. Here, as well, they were principally alluding to their own well-being, it was not as often mentioned that children as a group thrived on entertainment. In 38 percent of the conversations, learning, as something the 
children mentioned made them feel good was mentioned by the children themselves and when they related to children as a group. This was almost exclusively mentioned at school A.

\subsection{The body}

In order to further widen the children's thoughts as to well-being, questions were put concerning what makes the body feel good. The foremost things the children thought of were the basic needs, above all to eat/drink which was brought up in 46 percent of the conversations. After that they thought of the body feeling good from physical activity, which came up in a third of the interviews. One child described what makes the body feel good in this way:

"You should eat normally, not just junk food day and night, you should eat nutritious stuff".

\subsection{The conception of health}

In 54 percent of the interviews the children answered that they did not know the conception of health. In several cases the children connected the word health with the verb to greet, in Swedish these words are homonyms (Sw. hälsa and hälsa). This was particularly evident at school A, which can be linked to difficulties to do with language. In about a third of the interviews the children mentioned that health has to do with the basic needs, like eat right and feel good. Following are some examples of how some children described health; take care of your body, healthy eating, to exercise, not eat every five minutes, fat people who want to become thin.

\section{Discussion}

\subsection{Method}

Since the target group in the study was children, a qualitative approach was suitable. A considerable amount of today's research about children has been procured in this way; children often give comprehensive descriptions through words and pictures (Greig et al., 2007). To lessen possible sources of error, and to augment the reliability of the study, we had discussed external conditions and our attitude towards the children. The double coding of the material gave, according to Miles' and Huberman's (1994) reasoning about reliability, an authentic result, with the reliability higher than 70 percent. The two methods complemented each other since some children find it easier to express themselves through pictures than words (Pridmore \& Bendelow, 1995). It went well to converse with the children about this kind of questions, and one reason for that was that we got to know them before the interviews started. The time spent in the field of research was important to us, and it had great significance for how the interviews would turn out (Doverborg \& Pramling Samuelsson, 2007; E. Johansson, 2003). We consider the credibility of the children's answers high for one thing because the result from the individual task corresponds with the result from the interviews. There were times however, when we felt that the children spoke from their own experiences, but gave answers instead that sounded like a repetition of things they had heard adults say. Can it be that in these instances the children say what they think we, as interviewers, want to hear? Surely, they often get to hear what adults consider important for 
children's well-being. The length of the interviews varied considerably, which can be explained in different ways. It could be due to how safe the children felt, to their mood and also to the fact that children are more or less talkative. Another thing that might influence the length of the interview is problems due to language difficulties, especially at school A where the majority of the children have a foreign background. Our aim with the separation of what made children themselves feel good on one hand, and what made children feel well as a group on the other in the interviews, was in order to see if the perspectives differed. Some children may find it easier to take themselves as a starting point; others may find it easier to take children as a group.

\subsection{Result}

According to the children in the study it is relations that is the single most important factor for their well-being. Relations to family and friends have the greatest importance. This category comes up in the majority of the conversations, and relations are a theme that was often brought up in the individual task. What the children describe, in texts and pictures, make them feel well is thereby in accordance with what they express orally. That good relations are important to children's health is nothing new and revolutionary, it has been shown in several studies (Kostenius, 2008; Piko \& Bak, 2006). However, it is remarkable that relations are so important to health for Swedish children, while children in other countries do not mention relations to the same extent at all (Onyango-Ouma et al., 2004; Pridmore \& Bendelow, 1995). That is why it is interesting to reflect on. For the children in Kenya (Onyango-Ouma et al., 2004) it is understandable if health and clean food are more important than good relations. Their conditions are quite different from those of the Swedish children, and to have basic needs met is not always granted. It is all the more noteworthy that the English children mention basic needs more often than relations (Pridmore \& Bendelow, 1995). Their conditions are similar to those of Swedish children and still the view on health differs in this respect. The study by Pridmore and Bendelow (1995) is, as well as Kostenius' (2008) qualitative and the children should have had the same opportunities to express themselves concerning health. Some allowance must be made for the fact that the study by Pridmore and Bendelow is considerably older than Kostenius', and that children's perspectives on health might have changed since.

Physical activity was also very important for children's health, at least when they talked about themselves. Team sports were mentioned most often. Many children said that team sports were fun because there they get new friends and feel fellowship with others. Can it be that the sense of belonging is more important than the sport itself? In that case it is again relations that have the greatest significance for the children. The importance of physical activity is a factor which has been brought up in some studies (Onyango-Ouma et al., 2004; Piko \& Bak, 2006; Pridmore \& Bendelow, 1995) but not in the Swedish one (Kostenius, 2008). The basic needs were almost as important to children's well-being as exercise, especially to eat/drink. This factor has also proved important to children's health in other countries (Onyango-Ouma et al., 2004; Pridmore \& Bendelow, 1995). They hardly ever mentioned that they themselves felt good from eating/drinking, but however that other children benefit from it. That may be because they take the basic needs for granted and that 
they do not think about that that gives them health. A majority of Swedish children have a good standard of living and do not have to worry about not getting enough to eat and drink. When they say that children as a group benefit from it, they might be thinking of children in other countries that do not have a supply of food and drink. This shows that the children have the capacity to think outside themselves.

\section{Conclusion}

The object with this study is to investigate children's perspectives on health; what makes them feel well. According to the children in this study it is social and familial relations that are the most important for good health. Other factors like physical activity and basic needs were also of great importance but were not mentioned at all as often as relations. In the present situation The Health Adventure already works in this field, mainly through parenthood, friendship and relations. The health educationists' ideas about what children need in order to feel well are therefore in line with children's perspectives on health. Through the study the children had opportunities to express themselves, but in order to really make use of children's perspectives it is also required that their participation leads to influence, and that their views are properly considered (Pramling Samuelsson \& Sheridan, 2003). From this follows that The Health Adventure should further develop their work concerning how children could be made to partake in the shaping of the health interventions (Kalnins et al., 1992; Ryan, 1998). How can the fields of parenthood, friendship and relations develop together with the children, and what, concerning contents and working methods, can children influence? And what do they want to influence? If The Health Adventure utilizes the children's perspectives several benefits will be gained. On one hand the organisation works according to the Child Convention and Article 12, children's right to make their voices heard (Unicef, 2008). On the other hand The Health Adventure enhances children's possibilities to participation and influence, factors that promote their health (Wennerholm Juslin \& Bremberg, 2004). As to research in the future, it would be interesting to investigate young people's perspectives on health, and whether their views are different from those of the children.

\section{Acknowledgement}

This study was funded by The Health Adventure the Oasis Vara, Gunnareds stadsdelsförvaltning and University West in Trollhättan. I want to thank everybody that made the study possible - My supervisor Lena Nilsson, Phd in Pedagogics and Senior Lecturer at University West, my collaborators Lisa Flink, Sara Hellgren and Camilla Oldberg and my colleagues at The Health Adventure. I especially want to thank the children who participated in the study.

\section{References}

Alderson, P. (2004). Etics. Doing research with children and young people. (pp. 97-113). London: SAGE Publications.

Alerby, E. (2003). During the break we have fun: A study concerning schoolchildren's experience of school. Educational Research, 45, pp.17-28. 
http://dx.doi.org/10.1080/0013188032000086091s

Barnombudsmannen. (2009). Kom närmare. Om att överbrygga avståndet mellan barn och vuxna. En rapport från Barnombudsmannen 2009. Stockholm: Barnombudsmannen.

Birtwistle, G., \& Brodie, D. (1991). Children's attitudes towards activity and perceptions of physical education. Health education research, 6, pp.465-478. http://dx.doi.org/10.1093/her/6.4.465

Christensen, P., \& James, A. (2008). Introduction: Researching children and childhood cultures of communication. Research with children: Perspectives and Practices. (pp. 1-10). New York: The Falmer Press.

Danielsson, M. (2006). Svenska skolbarns hälsovanor 2005/2006. [Online] Available: http://www.fhi.se/PageFiles/3991/svenska_skolbarns_halsovanor(1).pdf (June 29, 2010).

Doverborg, E., \& Pramling Samuelsson, I. (2007). Att förstå barn tankar. Stockholm: Liber AB.

Greig, A., Taylor, J., \& Mackay, T. (2007). Doing research with children. (2nd ed.). London: Sage Publications.

Hesketh, K., Waters, E., Green, J., Salmon, L., \& Williams, J. (2005). Healthy eating, activity and obesity prevention: a qualitative study of parent and child perceptions in Australia. Health promotion international, 20, pp.19-26. http://dx.doi.org/10.1093/heapro/dah503

Hill, M. (2005). Ethical considerations in researching children's experiences. Researching children's experience. Approaches and methods. (pp. 61-87). Thousand Oaks: SAGE Publications.

Hume, C., Salmon, J., \& Ball, K. (2005). Children's perceptions of their home and neighborhood environments, and their association with objectively measured physical activity: a qualitative and quantitative study. Health education research, 20, pp.1-13. http://dx.doi.org/10.1093/her/cyg095

James, A., \& Prout, A. (1997). A new paradigm for the sociology of childhood? Provenance, promise and problems. Constructing and reconstructing childhood. Contemporary issues in the sociological study of childhood (pp. 1-34). Philadelphia: RoutledgeFalmer.

Johansson, A., Brunnberg, E., \& Eriksson, C. (2007). Adolescent Girls' and Boys' Perceptions of Mental Health. Journal of youth studies, 10, pp.183-202. http://dx.doi.org/10.1080/13676260601055409

Johansson, E. (2003). Att närma sig barns perspektiv. Forskares och pedagogers möten med barns perspektiv. Pedagogisk forskning i Sverige, 8, pp.42-57.

Kalnins, I., McQueen, D., Backett, K., Curtice, L., \& Currie, C. (1992). Children, empowerment and health promotion: some new directions in research and practice. Health promotion international, 7, pp.53-59. http://dx.doi.org/10.1093/heapro/7.1.53 
Kostenius, C. (2008). Giving Voice and Space to children in Health Promotion. Luleå tekniska universitet, Luleå.

Matthews, S. (2007). A Window on the "New" Sociology of Childhood. Sociology Compass, 1, pp.322-334. http://dx.doi.org/10.1111/j.1751-9020.2007.00001.x

Miles, M., \& Huberman, M. (1994). Qualitative data analysis: an expanded sourcebook. Thousand Oaks: SAGE Publications.

Nilsson, L. (2008). Vad är ett hälsoäventyr? Teoribas och diskussion kring upplevelse- och hälsoäventyrspedagogik. Högskolan Väst, Trollhättan.

Onyango-Ouma, W., Aargaard-Hansen, J., \& Jensen, B. B. (2004). Changing concepts of health and illness among children of primary school age in western Kenya. Health education research, 19, pp.326-339. http://dx.doi.org/10.1093/her/cyg034

Piko, B., \& Bak, J. (2006). Children's perceptions of health and illness: images and lay concepts in preadolescence. Health education research, 21, pp.643-653. http://dx.doi.org/10.1093/her/cyl034

Pramling Samuelsson, I., \& Sheridan, S. (2003). Delaktighet som värdering och pedagogik. Pedagogisk forskning i Sverige, 8, pp.70-84.

Pridmore, P., \& Bendelow, G. (1995). Images of health: exploring beliefs of children using the "draw-and-write" technique. Health education journal, 54, pp.473-488. http://dx.doi.org/10.1177/001789699505400410

Prout, A. (2005). The future of childhood: Towards the interdisciplinary study of children. New York: RoutledgeFalmer.

Ryan, N. (1998). The stress-coping process in school-age children: gaps in the knowledge needed for health promotion. Advanced Nursing Science, 11, pp.1-12.

Skolverket, Socialstyrelsen, \& Statens folkhälsoinstitut. (2004). Tänk långsiktigt! En samhällsekonomisk modell för prioriteringar som påverkar barns psykiska hälsa. [Online] Available: http://www.fhi.se/PageFiles/3233/R200414tanklangsiktigt.pdf (June 29, 2010).

Socialstyrelsen. (2009). Folkhälsorapport 2009. [Online] Available: http://www.socialstyrelsen.se/Lists/Artikelkatalog/Attachments/8495/2009-126-71_20091267 1.pdf (May 17, 2010).

Unicef. (2008). Handbok om barnkonventionen. Stockholm: UNICEF Sverige.

Wennerholm Juslin, P., \& Bremberg, S. (2004). När barn och ungdomar får bestämma mer påverkas hälsan. En systematisk forskningsöversikt. Stockholm: Statens folkhälsoinstitut.

\section{Copyright Disclaimer}

Copyright reserved by the author(s).

This article is an open-access article distributed under the terms and conditions of the Creative Commons Attribution license (http://creativecommons.org/licenses/by/3.0/). 